\section{Is there any association between renal failure and hepatotoxic photosensitization caused by feeding foxtail millet (Setaria italica) in sheep and goats?}

\author{
Arash Omidi, 1 \\ Fateme Izadi Yazdanabadi, 2 \\ Ukabed Esmaeilpour ${ }^{3}$
}

1Department of Animal Health

Management, School of Veterinary

Medicine, Shiraz University; ${ }^{2}$ Department

of Animal Science, Faculty of Agriculture,

University of Tabriz; ${ }^{3}$ Department of

Animal Science, Faculty of Agriculture,

University of Birjand, Iran

\section{Abstract}

Photosensitivity is an abnormal skin reaction to direct sunlight exposure. Photosensitivity occurred because of failure to excrete phylloerythrin due to hepatic dysfunction. Foxtail millet feeding can induce hepatotoxic photosensitization and influence on different organs. This study attempts to evaluate renal function and serum electrolyte status in sheep and goats experimentally feeding foxtail millet. Twelve male goats and sheep were kept in the sunlight. The animals were fed foxtail millet diet freely in a eight-week experimental period. Blood urea nitrogen (BUN), creatinine, sodium, potassium, phosphorus, magnesium, hematocrit and hemoglobin were measured until last day of experiment in a weekly manner. On the last day, the animals were euthanized and kidneys were removed for pathologic examination. Data were analyzed using repeated measurement analysis by SPSS software (version 20). Three sheep showed clinical signs of photosensitivity. BUN showed a decreasing trend from the second week of the experiment. Creatinine was increased in the six and second weeks. An increase in sodium concentration in goats from fourth week was significant. Sodium levels in sheep showed a fluctuational change. Potassium and phosphorus of sheep and phosphorus in the blood of goats were increased from the second week. Potassium in goats was constant during the time. Magnesium in the blood of sheep and goats was increased from the third and fourth weeks, respectively. The hematocrit and hemoglobin increased significantly over time. Moderate to severe hyperemia with abundant deposits of blue-violet material in the collecting ducts and mild degenerative changes in the convoluted tubules in sheep kidneys and congestion in the center of the goats' kidney were seen. In conclusion, feeding the foxtail millet can cause renal dysfunction, and changes in the balance of some serum electrolytes.

\section{Introduction}

Phylloerythrin is the photodynamic agent in sensitivity to light by origin of liver toxicity. Hepatogenous photosensitization is the most frequent type of photosensitivity observed in livestock. Phylloerythrin is derived from the breakdown of chlorophyll by microorganisms present in the gastrointestinal tract. Photosensitivity occurred because of failure to excrete phylloerythrin due to hepatic or renal dysfunction. ${ }^{1}$ Oxidative damage will be seen after accumulation of phylloerythrin in the derm and exposed the skin to the sun's ultraviolet radiation.2 Various species of millet, due to substances such as oxalates, steroidal saponines, nitrate and cyanogenic products can cause hepatogenic photosensitization in animals. ${ }^{3,4}$ Saponines are the most important factors in creating this type of hepatogenic photosensitization.5 Various plants cause hepatogenic photosensitization by the mechanisms of liver dysfunction 6 and species of millet such as Panicum dichotomiflorum cause sensitivity to light in sheep, horse, goats and cattle. ${ }^{7}$ There are sporadic reports of photosensitization associated with liver dysfunction in Iran. There is a report from a flock with 253 sheep grazed on Panicum miliaceum, in the Fars province. ${ }^{8}$ Varying degrees of jaundice and the pallor of mucous membranes induced by liver damages were found in further study in sheep experimentally intoxicated with this type of millet. ${ }^{9}$ In an experimental study in sheep and goats, the hepatogenic photosensitization was found during feeding Tribulus terrestris.10,11 Sheep and goats in some areas of Iran such as South Khorasan province were fed foxtail millet (Setaria italica) (Figure 1) routinely. ${ }^{12}$ The first place for production of foxtail millet in the country is the city of Birjand. The authors have been confirmed hepatotoxic photosensitization and impairment of different organs except kidneys in sheep and goats by experimentally feeding foxtail millet.3,13 According to the literatures, effects of foxtail millet on kidney have not been performed yet. This study attempts to evaluate the renal function and serum electrolyte status in sheep and goats experimentally feeding foxtail millet.

\section{Materials and Methods}

The study was done during the summer
Correspondence: Arash Omidi, Department of Animal Health Management, School of Veterinary Medicine, Shiraz University, Fars, Shiraz, Iran. E-mail: aomidi@shirazu.ac.ir

Key words: Foxtail millet; Goat; Hepatotoxic photosensitization; Kidney lesions; Sheep.

Conflict of interest: the authors declare no potential conflict of interest.

Acknowledgement: this article was extracted from the thesis prepared by Fateme Izadi Yazdanabadi and Ukabed Esmaeilpour to fulfill the requirements required for earning the Master of Science degree in animal physiology.

Funding: the authors gratefully acknowledge the financial support for this work that was provided by the Vice Chancellor for Research at Birjand University. The Research Council of Shiraz University is also sincerely appreciated. We also wish to appreciate of staff members of the Department of Animal Health Management in Shiraz University.

Received for publication: 27 August 2015.

Revision received: 18 October 2015.

Accepted for publication: 22 October 2015.

This work is licensed under a Creative Commons Attribution NonCommercial 4.0 License (CC BYNC 4.0).

(C) Copyright A. Omidi, et al., 2016

Licensee PAGEPress srl, Italy

Veterinary Science Development 2016; 6:6168 doi:10.4081/vsd.2016.6168

2010, in the Animal Husbandry Station of Birjand University. Birjand climate is dry, with intense sun radiation. Six male Balluchi sheep (weight of $21 \pm 2 \mathrm{~kg}$ ), white and six native male goats (average weight of $16.5 \pm 2.5 \mathrm{~kg}$ ) dark with age of four to five months were kept under the same conditions. Foxtail millet grass harvested in vegetative, flowering and seed formation steps. All procedures were performed based on the research of Izadi and colleagues.12 Harvested forages moved to the shade at any stage and after drying and packaging, were stored in order to feed the animals. Before starting the study, vaccination, and use of anti-parasitic drugs (Albendazole and ivermectin, Erfan Darou, Iran) in routine procedures were performed. Sheep and goats were kept for two weeks before feeding foxtail millet in the open air in the enclosed space (twenty square meters for sheep and goats that was separated by wire mesh) and without protection against sunlight for adaptation to new environments. At this time, sheep and goats had free access to alfalfa and tap water. The study lasted for 10 weeks (two weeks 
adaptation period, eight weeks, feeding millet). Animals received foxtail millet and water ad libitum. Weighing and blood sampling were done in weekly manner. The results of the first blood sampling (before taking foxtail millet) were considered as a control group. Blood samples were centrifuged at $750 \mathrm{~g}$ for 10 minutes. Serum was frozen at $-20^{\circ} \mathrm{C}$ until further analysis. Two milliliter of blood was taken in the tubes containing ethylenediamine tetraacetic acid (EDTA) anticoagulant for hemoglobin and hematocrit determination. The autoanalyzer (Prestige, 24i, Japan) was used to measure blood parameters. Mg was determined by colorimetric method using xylidyl blue ${ }^{14}$ and plasma phosphorus was measured by photometric method. 15 The amount of sodium and potassium was determined by flame photometer (SEACFP20, Japan). 16 Creatinine was measured by JAFFE method.17 Urea in serum was measured by photometric method based on Urease- GLDH. ${ }^{18}$ Hematocrit was expressed in terms of the volume of red blood cells in 100 $\mathrm{mL}$ of blood. Determination of hematocrit was performed by specific centrifugation for hematocrit. Hemoglobin was determined by counter apparatus.19 Pars Azmoon diagnostic kits (Iran) were used for measuring the variables. On the last day, the animals were euthanized and kidneys were removed for the pathologic examination. The samples fixed in $10 \%$ formalin buffer at room temperature. After fixing the tissue, it was thoroughly washed under running water and dehydrated in ascending grades of ethyl alcohol, cleared, and embedded in soft paraffin. Tissue sections of about $5 \mathrm{~m}$ were obtained, and stained using hematoxylin and eosin (H\&E) staining method, and examined under light microscope. ${ }^{20}$ SPSS (version 20) was used for data analysis. Determine the

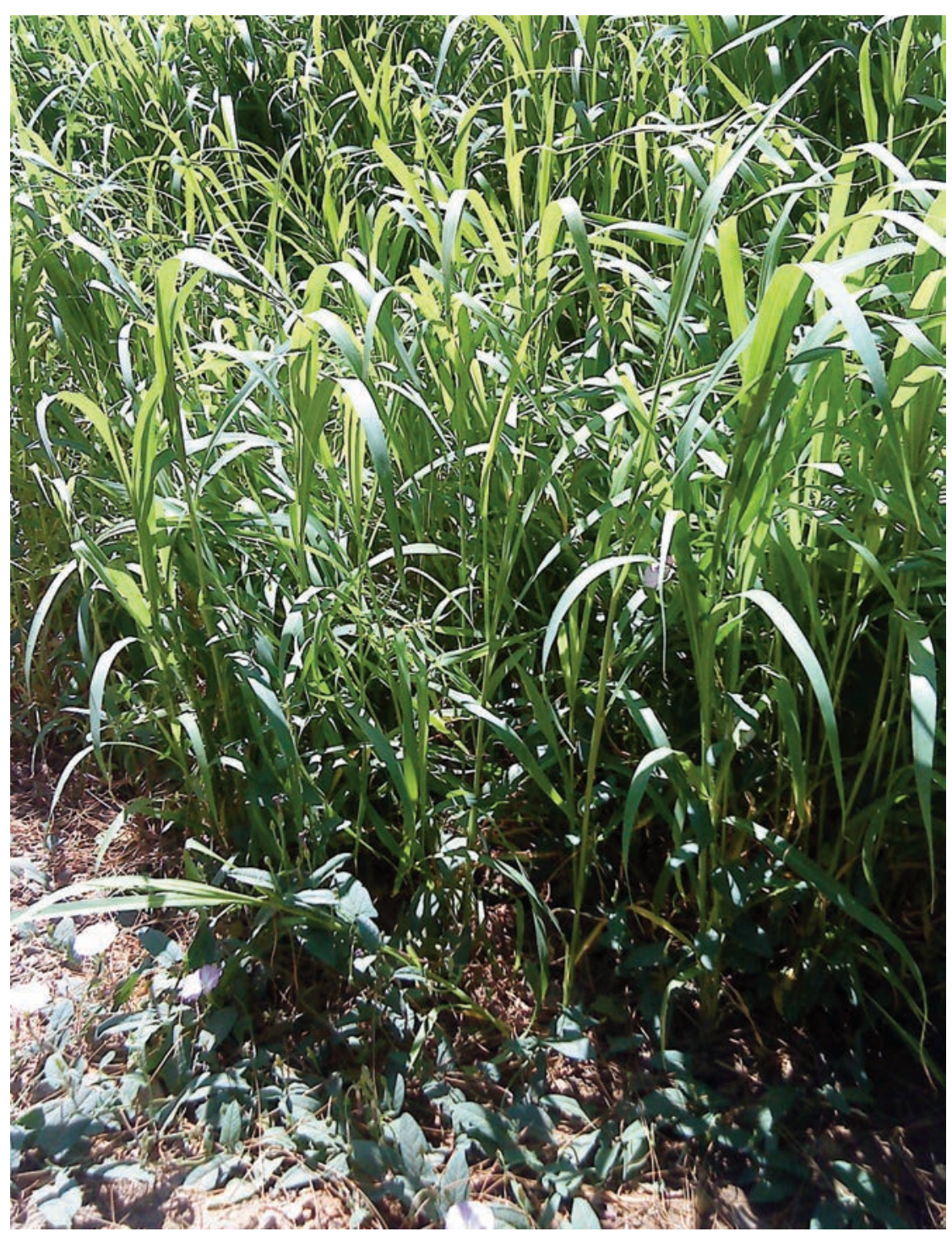

Figure 1. Foxtail millet (Setaria italica) used in the study.

Table 1. Mean \pm standard deviation of blood urea nitrogen and creatinine in sheep and goats fed foxtail millet within eight weeks of study (twelve sheep and goats).

\begin{tabular}{|c|c|c|c|c|c|c|c|c|c|}
\hline Variable & Animal & First week & Second week & Third week & Fourth week & Fifth week & Sixth week & Seventh week & Eighth week \\
\hline $\begin{array}{l}\text { Blood urea } \\
\text { nitrogen, } \\
\text { mg/dL }\end{array}$ & $\begin{array}{c}\text { Sheep (6) } \\
\text { Goat (6) }\end{array}$ & $\begin{array}{c}34.5 \pm 7.34 \\
37.16 \pm 1.77\end{array}$ & $\begin{array}{c}24.83 \pm 1.94^{*} \\
26.5 \pm 2.14^{*}\end{array}$ & $\begin{array}{l}22.33 \pm 6.12 * \\
25.20 \pm 2.98 *\end{array}$ & $\begin{array}{c}23.33 \pm 2.16^{*} \\
26.5 \pm 3.11^{*}\end{array}$ & $\begin{array}{l}23.16 \pm 3.71^{*} \\
20.50 \pm 3.31^{*}\end{array}$ & $\begin{array}{l}15.83 \pm 3.92^{*} \\
11.66 \pm 3.33^{*}\end{array}$ & $\begin{array}{l}12.16 \pm 2.92^{*} \\
10.66 \pm 2.67^{*}\end{array}$ & $\begin{array}{l}10.83 \pm 1.16^{*} \\
14.50 \pm 3.04^{*}\end{array}$ \\
\hline $\begin{array}{l}\text { Creatinine, } \\
\mathrm{mg} / \mathrm{dL}\end{array}$ & $\begin{array}{c}\text { Sheep (6) } \\
\text { Goat (6) }\end{array}$ & $\begin{array}{c}0.60 \pm 0.08 \\
0.1 \pm 0.01\end{array}$ & $\begin{array}{c}0.60 \pm 0.06 \\
0.11 \pm 0.00 *\end{array}$ & $\begin{array}{c}0.55 \pm 0.05 \\
0.15 \pm 0.01 *\end{array}$ & $\begin{array}{c}0.58 \pm 0.04 \\
0.13 \pm 0.01^{*}\end{array}$ & $\begin{array}{c}0.65 \pm 0.08 \\
0.16 \pm 0.01^{*}\end{array}$ & $\begin{array}{l}0.70 \pm 0.08^{*} \\
0.15 \pm 0.01^{*}\end{array}$ & $\begin{array}{l}0.71 \pm 0.04^{*} \\
0.12 \pm 0.01^{*}\end{array}$ & $\begin{array}{c}0.73 \pm 0.05^{*} \\
0.12 \pm 0.0^{*}\end{array}$ \\
\hline
\end{tabular}

Table 2. Mean \pm standard deviation of sodium, potassium, magnesium and phosphorus in sheep and goats fed foxtail millet within eight weeks of study (twelve sheep and goats).

\begin{tabular}{|c|c|c|c|c|c|c|c|c|c|}
\hline Variable & Animal & First week & Second week & Third week & Fourth week & Fifth week & Sixth week & Seventh weel & Eighth week \\
\hline $\mathrm{Na}, \mathrm{meq} / \mathrm{L}$ & $\begin{array}{l}\text { Sheep (6) } \\
\text { Goat (6) }\end{array}$ & $\begin{array}{l}142.33 \pm 3.72 \\
154.83 \pm 1.85\end{array}$ & $\begin{array}{l}139.33 \pm 5.35 \\
160.67 \pm 2.91\end{array}$ & $\begin{array}{l}140.67 \pm 2.42 \\
160.83 \pm 1.47\end{array}$ & $\begin{array}{c}143.33 \pm 4.32 \\
169.17 \pm 0.98^{*}\end{array}$ & $\begin{array}{c}137.50 \pm 2.34^{*} \\
163.5 \pm 2.15^{*}\end{array}$ & $\begin{array}{c}145 \pm 4.04 \\
167.5 \pm 1.38 *\end{array}$ & $\begin{array}{c}142 \pm 6.63 \\
164 \pm 1.59 *\end{array}$ & $\begin{array}{c}147.67 \pm 3.82^{*} \\
166 \pm 1.56^{*}\end{array}$ \\
\hline $\mathrm{K}, \mathrm{meq} / \mathrm{L}$ & $\begin{array}{l}\text { Sheep (6) } \\
\text { Goat (6) }\end{array}$ & $\begin{array}{c}3.83 \pm 0.163 \\
6.15 \pm 0.29\end{array}$ & $\begin{array}{l}5.2 \pm 0.91 * \\
6.16 \pm 0.18\end{array}$ & $\begin{array}{l}5.2 \pm 0.19^{*} \\
6.10 \pm 0.16\end{array}$ & $\begin{array}{l}5.3 \pm 0.25^{*} \\
6.53 \pm 0.17\end{array}$ & $\begin{array}{c}4.68 \pm 0.39 * \\
6.08 \pm 0.14\end{array}$ & $\begin{array}{c}4.65 \pm 0.17 * \\
6.26 \pm 0.1\end{array}$ & $\begin{array}{c}4.61 \pm 0.11 * \\
6.06 \pm 0.16\end{array}$ & $\begin{array}{c}4.58 \pm 0.17 * \\
6.06 \pm 0.18\end{array}$ \\
\hline $\mathrm{Mg}, \mathrm{mg} / \mathrm{dL}$ & $\begin{array}{l}\text { Sheep (6) } \\
\text { Goat (6) }\end{array}$ & $\begin{array}{l}2.11 \pm 0.36 \\
2.57 \pm 0.16\end{array}$ & $\begin{array}{l}2.48 \pm 0.88 \\
2.72 \pm 0.13\end{array}$ & $\begin{array}{c}2.51 \pm 0.49 * \\
2.79 \pm 0.11\end{array}$ & $\begin{array}{l}2.54 \pm 0.31 * \\
2.93 \pm 0.14^{*}\end{array}$ & $\begin{array}{c}2.62 \pm 0.23^{*} \\
3.0 \pm 0.18^{*}\end{array}$ & $\begin{array}{l}3.29 \pm 0.38 * \\
3.72 \pm 0.27 *\end{array}$ & $\begin{array}{l}3.30 \pm 0.48^{*} \\
3.55 \pm 0.24^{*}\end{array}$ & $\begin{array}{l}3.43 \pm 0.69 * \\
3.85 \pm 0.21 *\end{array}$ \\
\hline $\mathrm{P}, \mathrm{mg} / \mathrm{dL}$ & $\begin{array}{l}\text { Sheep (6) } \\
\text { Goat (6) }\end{array}$ & $\begin{array}{l}9.13 \pm 0.37 \\
6.55 \pm 0.17\end{array}$ & $\begin{array}{c}11.11 \pm 1.15^{*} \\
9.85 \pm 1.02^{*}\end{array}$ & $\begin{array}{l}11.28 \pm 1.34 * \\
8.98 \pm 0.89 *\end{array}$ & $\begin{array}{l}12.58 \pm 1.95^{*} \\
10.33 \pm 0.23^{*}\end{array}$ & $\begin{array}{c}11.9 \pm 1.71^{*} \\
10.33 \pm 0.24^{*}\end{array}$ & $\begin{array}{l}12.45 \pm 2.37^{*} \\
10.36 \pm 1.23^{*}\end{array}$ & $\begin{array}{l}11.38 \pm 1.92^{*} \\
10.91 \pm 1.16^{*}\end{array}$ & $\begin{array}{l}11.21 \pm 2.38^{*} \\
10.23 \pm 0.66^{*}\end{array}$ \\
\hline
\end{tabular}

*Significant differences in sheep and goats respectively $(\mathrm{P} \leq 0.05)$. 
normality of the data was performed using the Kolmogorov-Smirnov test. The data are presented as mean \pm standard deviation (SD). Significant differences between the various experimental parameters measured in weeks rather than the first week was performed by repeated measurement using the Least Significant Difference (LSD) test. Differences in $\mathrm{P}<0.05$ were considered significant.

\section{Results}

At the end of the study, three lambs showed clinical signs of hepatogenic photosensitization including erosions and ulcers in head, face, ears and eyelids. Ears hyperemia, yellowish sclera and congectiva and mild inflammation of the face were also noticed. Clinical and dermal signs in goats were lesser than sheep. In three goats, ear hyperemia, mild yellowish sclera and conjunctiva, and mild inflammation of face were seen. In sheep and goats, a loose defecation (not diarrhea) was seen form the second weeks of the experiment. The level of BUN, creatinine, electrolytes, pack cell volume (PCV) and hemoglobin ( $\mathrm{Hb})$ showed significant changes during the experiment in comparison with first time of bleeding in goats and sheep $(\mathrm{P} \leq 0.05)$. Potassium level was constant during the study. The BUN decreased from the second weeks of study. The level of creatinine from $6^{\text {th }}$ week and from the $2^{\text {nd }}$ week showed significant differences in sheep and goats respectively $(\mathrm{P} \leq 0.05)$ (Table 1$)$. Gradually increasing the concentration of sodium in goats was seen. This increased level was significant from $4^{\text {th }}$ week of the experiment $(\mathrm{P} \leq 0.05)$. The amount of sodium in sheep showed significant fluctuation alterations. The potassium and phosphorus in the blood of sheep and phosphorus levels in the blood of goats increased from the second week. The blood magnesium in sheep and goats were increased in the third and fourth weeks (Table 2). Hematocrit and hemoglobin levels were significantly increased over time $(\mathrm{P} \leq 0.05)$ (Table 3). In both animals kidney failures was

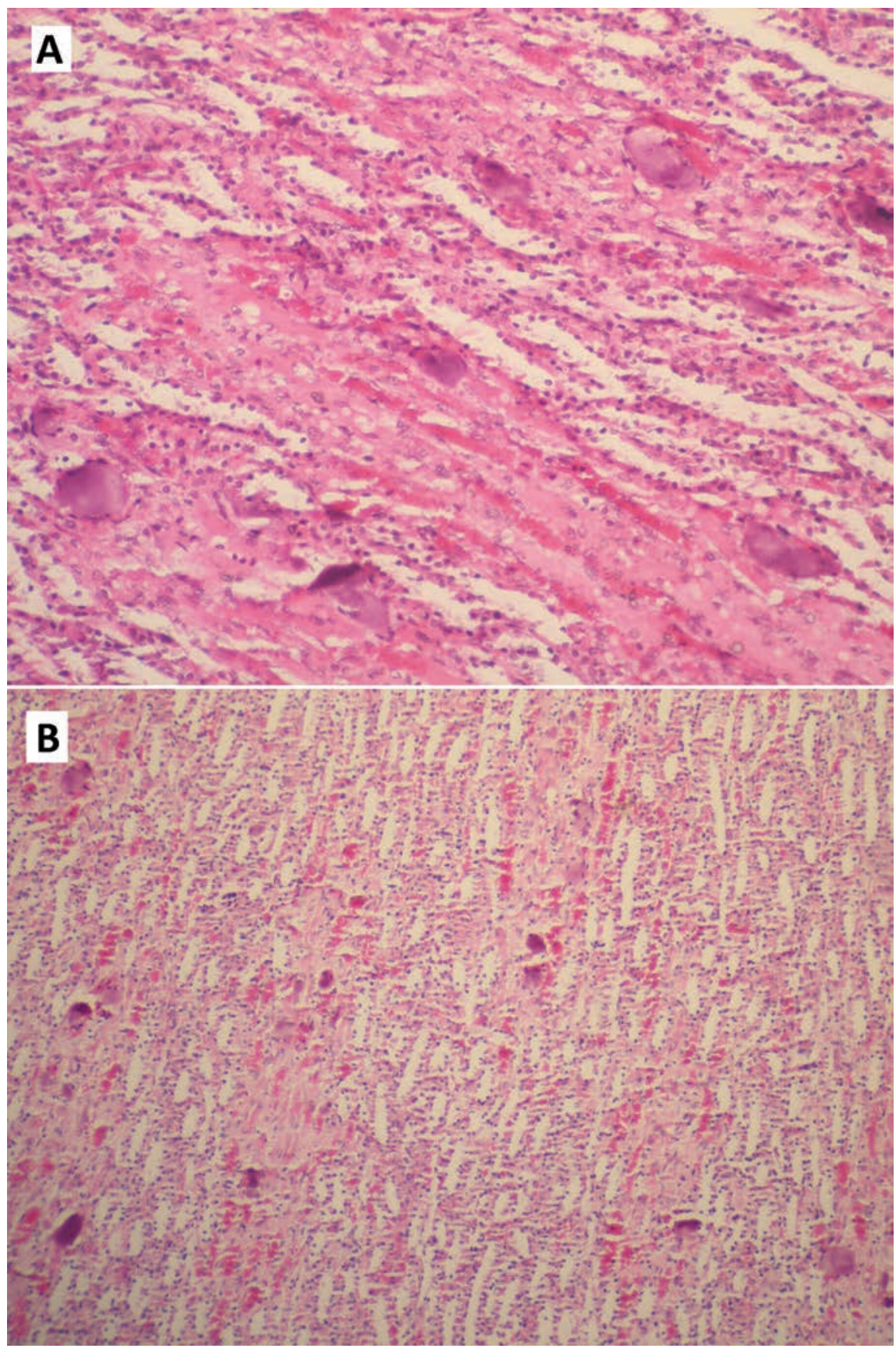

Figure 2. Congestion and the presence of blue, purple sediments along with mild degenerative changes in the convoluted ducts of kidney in sheep (A and $B$ ). observed in the pathological examinations. Moderate to severe congestion with the pre-

Table 3. Mean \pm standard deviation of hematocrit and hemoglobin in sheep and goats fed foxtail millet within eight weeks of study(twelve sheep and goats).

\begin{tabular}{|c|c|c|c|c|c|c|c|c|c|}
\hline Variable & Animal & First week & Second week & Third week & Fourth week & Fifth week & Sixth week & Seventh wee & Eighth week \\
\hline $\begin{array}{l}\text { Hematocrit } \\
\text { (pack cell } \\
\text { volume), g/dL }\end{array}$ & $\begin{array}{c}\text { Sheep (6) } \\
\text { Goat (6) }\end{array}$ & $\begin{array}{l}25.4 \pm 1.93 \\
25.5 \pm 1.11\end{array}$ & $\begin{array}{c}31.4 \pm 1.6 \\
30.33 \pm 0.55^{*}\end{array}$ & $\begin{array}{c}30.8 \pm 1.98 \\
30.16 \pm 1.35 *\end{array}$ & $\begin{array}{c}37.6 \pm 1.03^{*} \\
35.33 \pm 1.28^{*}\end{array}$ & $\begin{array}{l}36.8 \\
32.5\end{array}$ & $\begin{array}{l}36.4 \pm 1.66^{*} \\
36.0 \pm 1.05^{*}\end{array}$ & $\begin{array}{c}33.4 \pm 1.2^{*} \\
34.0 \pm 1.43^{*}\end{array}$ & $\begin{array}{l}2.31 \\
1.11^{*}\end{array}$ \\
\hline $\begin{array}{l}\text { Hemoglobin, } \\
\mathrm{g} / \mathrm{dL}\end{array}$ & $\begin{array}{c}\text { Sheep (6) } \\
\text { Goat (6) }\end{array}$ & $\begin{array}{l}8.78 \pm 0.99 \\
7.73 \pm 0.82\end{array}$ & $\begin{array}{c}9.6 \pm 0.82 \\
9.76 \pm 0.36\end{array}$ & $\begin{array}{c}10.10 \pm 1.09 \\
9.51 \pm 0.62\end{array}$ & $\begin{array}{c}10.73 \pm 0.85^{*} \\
11.05 \pm 0.4^{*}\end{array}$ & $\begin{array}{c}11.36 \pm 1.31 * \\
10.81 \pm 0.3^{*}\end{array}$ & $\begin{array}{l}11.51 \pm 0.73^{*} \\
11.08 \pm 0.16^{*}\end{array}$ & $\begin{array}{l}10.66 \pm 1.03^{*} \\
10.86 \pm .031^{*}\end{array}$ & $\begin{array}{l}10.48 \pm 1.17^{*} \\
11.31 \pm 0.29^{*}\end{array}$ \\
\hline
\end{tabular}

*Significant differences in sheep and goats respectively $(\mathrm{P} \leq 0.05)$. 
sence of great blue-purple materials (sediments) in collecting ducts along with mild to severe degenerative changes of convoluted tubules in kidney of sheep were found (Figure 2 ). The most significant findings were congestion in the center of the entire goats' kidney (Figure 3).

\section{Discussion and Conclusions}

Regardless of the mechanism or photodynamic agent, clinical signs in affected animals are similar. Animals show symptoms including restlessness, avoid of light and intense itching. Usually, animals with a dark color or those who are away from sunlight did not show apparent symptoms of photosensitivity. But animals with white skin, especially in parts without pigments show signs of photosensitivity in the exposed regions to the sun. ${ }^{10}$ In the present study, three sheep showed clinical signs of hepatogenic photosensitization at the end of the experiment. Observation of photosensitivity symptoms in sheep probably was due to white, less woolly and existence of abundant vessels in the affected area. Ears hyperemia, slight yellowish eyes and swollen face were seen in goats. Probably dark coat of goats, with the existence of pigments in the hair and skin, provides skin protection and absorbed light energy before to activate photodynamic agents and induced skin damage. ${ }^{1}$ In the study conducted by Badiei and colleagues, ${ }^{9}$ one of the sheep fed with Panicum miliaceum showed symptoms of photosensitivity include swelling of the eyelids, face and edema in lower jaw. Riet-Correa and colleagues, ${ }^{7}$ reported photosensitivity symptoms in sheep after feeding with Panicum dichotomiflorum include face edema, dermatitis (mainly on the face and ears), ocular discharge and redness of hoof crown. In this study, pathological examination of the kidneys, showed congestion and deposits in collecting ducts. Some degenerative changes were observed in the convoluted tubules of sheep kidney. Congestion in the center of the kidney of goats was seen. These observed lesions are in agreement with reports of natural and experimental poisoning by plants with saponins. Aslani and colleagues ${ }^{10,11}$ on experimental sheep poisoning by Tribulus tristris, were observed renal inflammations, crystals in the tubules and necrosis. The presence of sediments or crystals in the renal tubules of sheep was reported by Brum and colleagues 4 in poisoning with Brachiaria decumbens. The BUN level was significantly reduced in sheep and goats from the second week $(\mathrm{P} \leq 0.05)$. Urea production is almost exclusively conducted in the liver. Low levels of BUN, probably seen due to decrease of liver active mass, were reported. ${ }^{8}$ The serum creatinine in sheep and goats showed an increasing trend over the experiment. In sheep, the mean concentration of creatinine in the first sampling time was significant compared to the sixth, seventh and eighth sampling $(\mathrm{P} \leq 0.05)$. Serum creatinine is a more accurate index for assessment of renal function. The concentration of serum creatinine is slightly affected by diet and catabolic factors. ${ }^{21}$ Increased levels of creatinine and BUN, due to kidney damages, were reported by Aslani and colleagues in the experimental feeIn a study on sheep fed Panicum miliaceum, a significant increase in BUN and creatinine was reported by Badiei and colleagues ${ }^{9}$ due to the effect of the plant on renal function. In the incidence of hepatogenous photosensitization in animals fed on Panicum miliaceum pasture, a significant increase in serum creatinine was observed by Nazifi and colleagues. ${ }^{8}$ Sodium concentration decreased and increased in sheep in swinging manner. The mean of the five and eight sampling times were statistically significant compared to the first sampling $(\mathrm{P} \leq 0.05)$. But significantly increased over the study period in goats $(\mathrm{P} \leq 0.05)$. Increase blood sodium is a sign of dehydration.22 No significant differences in the concentrations of sodium, potassium and phosphorus were observed in an experimental poisoning of sheep by Tribulus tristris. ${ }^{10}$ An increased potassium level was reported in experimental poisoning of goats by Tribulus tristris. ${ }^{11}$ No significant changes were found in the serum concentrations of sodium, and potassium, in feeding sheep by Panicum miliaceum. ${ }^{9}$ But phosphorus concentrations increased significantly due ding of Tribulus tristris to sheep ${ }^{11}$ and goats. ${ }^{10}$

to the effect of Panicum miliaceum on the function of the kidneys. The blood potassium levels significantly increased compared to the first sampling in sheep $(\mathrm{P} \leq 0.05)$. The higher blood potassium could be due to renal retention of potassium in acute renal failure and/or tissue necrosis. ${ }^{23}$ By reviewing the scientific literatures, any reason for the stability of serum potassium in goats during the study was not observed. The magnesium concentration was significantly increased in sheep and goats during the experimental period $(\mathrm{P} \leq 0.05)$. Increase blood magnesium can induce by renal failure. 8 The concentration of phosphorus in the evaluated animals during different weeks showed a significant increase compared to the first sampling time $(\mathrm{P} \leq 0.05)$. Kidney damage can lead to reduced glomerular filtration and increased blood phosphorus in sheep and goats. ${ }^{8,23}$ Increase blood hemoglobin in sheep and goats from the fourth to the eighth weeks of sampling was significant $(\mathrm{P} \leq 0.05)$. The hematocrit showed statistically significant increase in goats and sheep all the time and in the $4^{\text {th }}$ to the $7^{\text {th }}$ weeks of study, respectively $(\mathrm{P} \leq 0.05)$. Increased hematocrit or corpuscular volume also can help to confirm the clinical symptoms of dehydration. ${ }^{22}$ The reduction in BUN is due to kidney and liver damages from the second week of study. Despite the amount of creatinine in sheep increased later than goats (respectively from the sixth and second week), but the clinical signs and pathological lesions related to photosensitivity in all sheep were more severe than the goats. The color difference between sheep (white) and goats (dark) and biological diffe-

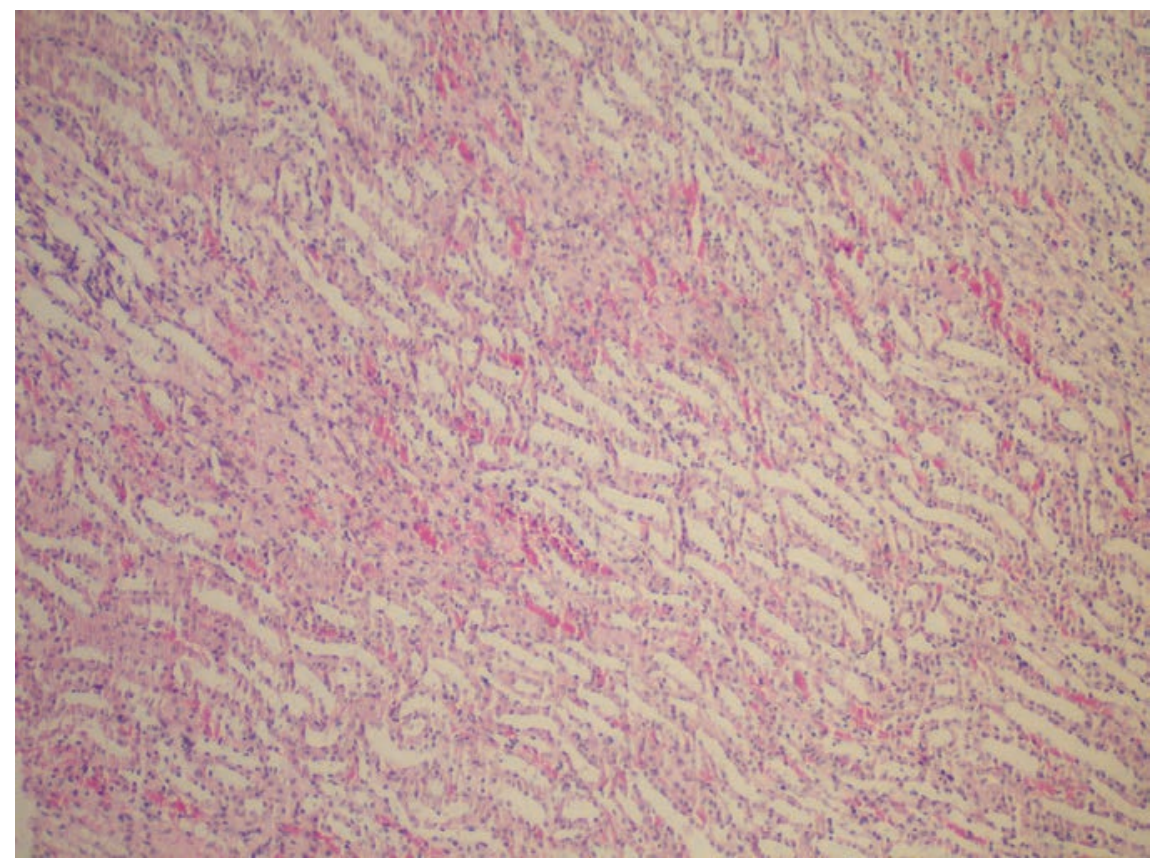

Figure 3. The congestion in the center of kidney in goats. 
rences between the species can be considered in the current event. Changes in electrolytes can be considered consistent with kidney failure. Use of millet pasture for grazing sheep and goats can be limited for up to a week. One of the limitations in this study was the problem that the first week samples were considered as control. However, conducting the experiments on the higher number of animals and using proper controls for each week of the experiment is recommended to overcome the limitations of the current study. The determination of Saponins and other natural compounds will also help to further research. ${ }^{24}$

\section{References}

1. Quinn JC, Kessell A, Weston LA. Secondary plant products causing photosensitization in grazing herbivores: their structure, activity and regulation. Int $\mathrm{J}$ Molec Sci 2014;15:1441-65.

2. Hegge AB, Mysterud I, Karlsen J, et al. Impaired secondary oxidant deactivation capacity and enhanced oxidative stress in serum from alveld affected lambs. $\mathrm{J}$ Photochem Photobiol B 2013;126:126-34.

3. Omidi A, Izadi Yazdanabadi F, Esmaeilpoor $\mathrm{U}$, et al. Hepatotoxicity in sheep and goats caused by experimental feeding with foxtail millet. Iran J Vet Med 2015;9:79-86.

4. Brum KB, Haraguchi M, Lemos RA, et al. Crystal-associated cholangiopathy in sheep grazing Brachiaria decumbens containing the saponin protodioscin. Pesq Vet Bras 2007;27:39-42.

5. De Oliveira CHS, Barbosa JD, Oliveira CMC, et al. Hepatic photosensitization in buffaloes intoxicated by Brachiaria decumbens in Minas Gerais state, Brazil. Toxicon 2013;73:121-9.
6. Movahedian A, Asgary S, Mansoorkhani HS, Keshvari M. Hepatotoxicity effect of some Iranian medicinal herbal formulation on rats. Adv Biomed Res 2014;3:1-5.

7. Riet-Correa F, Haraguchi M, Dantas AFM, et al. Sheep poisoning by Panicum dichotomiflorum in northeastern Brazil. Pesq Vet Bras 2009;29:94-8.

8. Nazifi S, Ghane $M$, Fazeli $M$, et al. Prosomillet (Panicum miliaceum) poisoning in Iranian fat-tailed sheep. Comp Clin Pathol 2009;18:249-53.

9. Badiei K, Mostaghni K, Nazifi S, et al. Experimental panicum miliaceum poisoning in sheep. Small Ruminant Res 2009;82:99-104.

10. Aslani MR, Movassaghi AR, Mohri M, et al. Experimental Tribulus terrestris Poisoning in sheep: clinical, laboratory and pathological findings. Vet Res Comm 2003;27:53-62.

11. Aslani MR, Movassaghi AR, Mohri M, et al. Experimental tribulus terrestris poisoning in goats. Small Ruminant Res 2004;51:2617.

12. Izadi Yazdanabadi F, Esmailpor U, Omidi A, Behdani MA. Quality evaluation of Setaria italica in different stages of growth. J Agr Ecol 2013;5:282-8. [Article in Persian]

13. Omidi A, Esmaeilpour U, Izadi Yazdanabadi F. Histopathological observations in cardiac, lung, spleen, intestinal and testicular tissues in sheep and goats fed foxtail millet (Setaria italica), J Vet Res 2015;19:261-9.

14. Wu L, Luthringer BJ, Feyerabend F, et al. Effects of extracellular magnesium on the differentiation and function of human osteoclasts. Acta Biomater 2014;10:284354 .

15. Dao-ming LU, Shu Q, Guo-gang T. A study on the experimental conditions of determination of phosphorus by Tin chloride
Reduction spectro-photometry. J Zhenjiang Coll 2011;1:22.

16. Klaic PMA, Nunes AM, Moreira ADS, et al. Determination of $\mathrm{Na}, \mathrm{K}, \mathrm{Ca}$ and $\mathrm{Mg}$ in xanthan gum: sample treatment by acid digestion. Carbohyd Polym 2011;83:1895-900.

17. Fillée C, Vranken G, Othmane M, et al. Results of the recalibration of creatinine measurement with the modular Beckman Coulter® Jaffe creatinine method. Clin Chem Lab Med 2011;49:1987-99.

18. Lin GM, Li YH, Zheng NC, et al. Serum uric acid as an independent predictor of mortality in high-risk patients with obstructive coronary artery disease: a prospective observational cohort study from the ETCHD registry, 1997-2003. J Cardiol 2013;61:122-7.

19. Berkow L. Factors affecting hemoglobin measurement. J Clin Monit Comput 2013;27:499-508.

20. McGavin MD, Zachary JF. Pathologic Basis of Veterinary Disease $4^{\text {th }}$ ed. St. Louis, Missouri: Mosby-Elsevier; 2007. p 1476.

21. Bianchi AE, Macedo VP, França RT, et al. Effect of adding palm oil to the diet of dairy sheep on milk production and composition, function of liver and kidney, and the concentration of cholesterol, triglycerides and progesterone in blood serum. Small Ruminant Res 2014;117:78-83.

22. Combs MDA, Rendell D, Reed KFM, et al. Evidence of dehydration and electrolyte disturbances in cases of perennial ryegrass toxicosis in Australian sheep. Aust Vet J 2014;92:107-13.

23. Bellomo R, Kellum JA, Ronco C. Acute kidney injury. Lancet 2012;380:756-66.

24. Francis G, Kerem Z, Makkar HPS, Becker $K$. The biological action of saponins in animal systems. Br J Nutr 2002;88:587-604. 